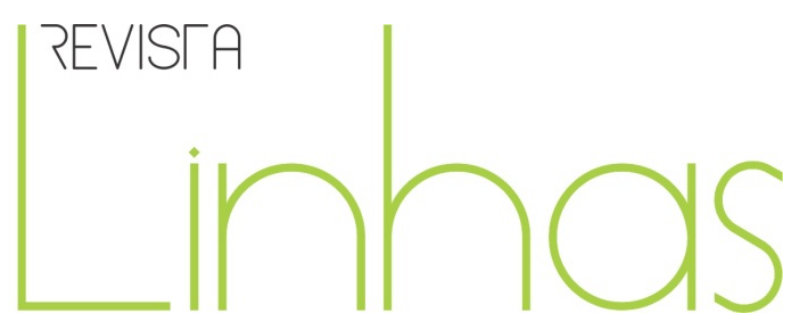

\title{
Fragmentos de uma História da Educação no Brasil
}

ARAÚJO, José Carlos Souza, SOUZA, Rosa Fátima de. PINTO, Rubia-Mar Nunes. Escola primária na primeira República (1889-1930): subsídios para uma história comparada. Araraquara, SP: Junqueira \& Marin, 2012.

\section{Cíntia Borges Almeida}

Mestre em Educação pela Universidade do Estado do Rio de Janeiro - UERJ. cintiaborgesalmeida@yahoo.com.br.br

\author{
Aline Morais Limeira \\ Doutoranda em Educação pela Universidade \\ do Estado do Rio de Janeiro - UERJ. \\ aline.de.morais@oi.com.br
}

\section{Para citar esta Resenha:}

ALMEIDA, Cíntia Borges; LIMEIRA, Aline Moraes. Fragmentos de uma História da Educação no Brasil. Revista Linhas, Florianópolis, v. 14, n. 26, jan./jun. 2013. p. $316-320$.

DOI: $10.5965 / 1984723814262013316$

http://dx.doi.org/10.5965/1984723814262013316 
É certo que a escola se tornou instituição privilegiada para dar forma ao projeto de instrução popular no Império. Muitos foram (são) os limites, problemas e soluções pensados e propostos desde então. A análise histórica, neste sentido, permite observar ambiências contemporâneas relativas à educação a partir de um olhar privilegiado; afinal, "voltar tão longe não é ceder à miragem das origens [...]. Isso pode permitir apreciar melhor a significação, a amplitude e também os limites recolocando-a em um contexto" (REVEL, 2010, p. 22).

Desta feita, saudamos a publicação de Escola Primária na Primeira República (18891930): subsídios para uma história comparada, cujo trabalho resulta de múltiplos investimentos: alunos e professores envolvidos com o campo da História da Educação no espaço de universidades e grupos de pesquisas. Lançado em 2012, este livro se estrutura em 11 capítulos, distribuídos em 351 páginas. A obra, organizada por José Carlos S. Araújo (UEB), Rosa Fátima de Souza (UNESP) e Rubia-Mar N. Pinto (UFG), pretendeu problematizar aspectos relacionados ao processo de escolarização, atinentes às experiências comuns e particulares em alguns estados do Brasil nos anos iniciais do regime republicano.

De um modo geral, o conjunto de pesquisas que é o livro reúne limites e avanços. Não nos sendo possível reafirmar que a "história dos grupos escolares se confunde com a história do ensino primário no Brasil" (p. 11) - visto que não se podem desconsiderar as recentes pesquisas que dão luz às iniciativas de escolarização no Império, como os Palácios Escolares, por exemplo -, destacamos que, entre os objetivos propostos pelos organizadores, há uma iniciativa sempre muito válida e atraente, constituída pela análise e circulação de fontes primárias'.

No que se refere à proposta de abordagem do investimento (comparativa), notase que procurou observar o que se entende por desarmonia regional, haja vista a grande diversidade de experiências de promoção do ensino no Brasil e a permanência de modelos anteriores à propagada "modernização" na República (escolas isoladas).

\footnotetext{
${ }^{1} O$ acervo que resultou da pesquisa foi publicado em DVD, intitulado Fontes para o Estudo da Escola Primária no Brasil (1889-1930).
} 
No caso do capítulo inicial, de autoria dos próprios organizadores, realizou-se uma apresentação da estrutura do projeto desenvolvido e dos termos postos em comparação, como métodos, materiais, representações, institucionalização, reformas.

Em São Paulo - 1893, Rosa Fátima de Souza procura abordar a institucionalização dos grupos escolares naquele estado, associando à análise aspectos gerais dos distintos movimentos políticos da época. Com efeito, nesta história produzida pela professora da UNESP, tornou-se possível observar a marca da heterogeneidade das experiências paulistas.

Professores e pesquisadores da UFMA, Iran Nunes, Diomar Graças, Elisângela Amorim e Acildo Silva, procuraram esquadrinhar aspectos legais do processo de escolarização no estado, sublinhando a profusão das leis do referido período. Em Maranhão - 1903, eles destacam os investimentos e resultados das ações do poder público na promoção da escola primária graduada.

José Carlos S. Araújo ocupou-se de Minas Gerais - 1906. O professor da UEB inquiriu elementos que circularam nos discursos dos dirigentes políticos daquele estado em momento de implantação da República, focando aspectos atinentes a educação e a ideais a ela associados.

Em Rio Grande do Norte - 1908, Marta Maria de Araújo e Marlúcia Menezes de Paiva propuseram-se refletir acerca de alguns projetos de escola primária pensados e alvitrados à época. As professoras da UFRN destacaram elementos da "modernização pedagógica” inscritos em reformas, ações públicas e iniciativas particulares.

Elizabeth Figueiredo de Sá averiguou vestígios da escolarização primária num estado de grande extensão territorial, ao analisar Mato Grosso - 1910. Obstáculos, projetos, aspirações, temas e experiências foram abordados em sua historicidade pela professora da UFMT que, a partir desta perspectiva, estranha as cronologias mais engessadas.

Em Piauí - 1910, Maria do Amparo B. Ferro apresentou dados sobre a "terra de passagem" (p. 195) e a inexistência de escolas públicas no início do século XIX. A professora da UFPI abalizou que, somente na República, se observou uma ampliação na escolarização representada pela implementação da obrigatoriedade do ensino primário, 
como também pela criação de grupos escolares, consolidando, assim, o sistema escolar do Piauí.

Jorge Carvalho do Nascimento visibilizou o Sergipe - 1911, tendo como principal interesse as transformações originadas pelas reformas educacionais no estado, assim como os modelos experimentados, a organização pedagógica, o processo de ampliação da malha escolar, além das medidas de financiamento aplicadas, dentre elas a ferramenta da caixa escolar. O uso da comparação ressaltou no texto do professor da UFS ao destacar que a escola primária seriada do Sergipe seguiu o modelo adotado em São Paulo, principalmente a experiência do grupo escolar.

Para analisar Bahia - 1913, Lúcia Maria F. Rocha deu mostras de uma crescente expansão da instrução primária no estado, a partir da apresentação de dados parciais acerca das matrículas e frequências na primeira República, tendo predominado até 19240 modelo de escolas elementares isoladas. A professora da UFBA assinalou que a educação permaneceu sendo uma grande preocupação para o governo.

Professoras da UFCA, Andréa Maria L. Dantas e Elizabeth M. Lima, discutiram, em Acre - 1915, aspectos relacionados à institucionalização da escola graduada do Acre. Assim, cientificaram que os grupos escolares foram implantados para acompanhar as inovações educacionais e formar os acreanos para vencer o atraso do estado em comparação ao restante do Brasil (p. 285).

Rúbia-Mar N. Pinto apontou, em Goiás - 1918, as estratégias escamoteadas nos discursos dos parlamentares, que negaram a existência do ensino primário no estado e/ou destacaram sua precariedade. Ao problematizar os discursos, a professora da UFG destacou que a criação, a organização e a administração das escolas eram reféns de acordos e negociações presentes no jogo político que ali se configurava.

Para arrematar as reflexões propostas pelo livro, as professoras Maria Cristina S. Gouvêia (UFMG) e Alessandra F.M Schueler (UFF) analisaram o projeto dos grupos escolares como um elemento do processo heterogêneo e multifacetado da educação no Brasil, discorrendo sobre o processo de consolidação do País, no qual a difusão da instrução elementar foi peça fundamental para a formação da nação. Ao apresentar as tensões que envolviam a organização escolar, anuímos à afirmação das autoras de que a 
História da Educação no Brasil foi marcada por desigualdades e restrições no acesso à cidadania.

O efeito deste investimento de muitas mãos é reflexivo. O nosso presente nos é comum, ordinário, embora incerto e duvidoso em relação aos efeitos que dele resultarão. Neste caso, a história ajuda a compreender melhor o que nos constitui; afinal, ela é "habitada pela estranheza que procura" (CERTEAU, 2007, p. 46). Destarte, observamos nas questões levantadas por esta História da Educação problemas que são nossos. Incontornáveis em sua atualidade, portanto.

\section{Referências bibliográficas}

ARAÚJO, José Carlos Souza, SOUZA, Rosa Fátima de. PINTO, Rubia-Mar Nunes. Escola primária na primeira República (1889-1930): subsídios para uma história comparada. Araraquara, SP: Junqueira \& Marin, 2012.

CERTEAU, Michel de. A Escrita da História. Trad. Maria de Lourdes Menezes. 2. ed. Rio de Janeiro: Forense Universitária, 2007.

REVEL, Jacques. História e Historiografia: exercícios críticos. Tradução Carmem Lúcia Druciak. Curitiba: Ed. UFPR, 2010.

Universidade do Estado de Santa Catarina - UDESC Programa de Pós-Graduação em Educação - PPGE Revista Linhas Volume 14 - Número 26 - Ano 2013 revistalinhas@gmail.com 